\title{
25-years of biomonitoring in two mediterranean streams (Llobregat and Besòs basins, NE Spain)
}

\author{
Narcís Prat*, Maria Rieradevall \\ F.E.M. (Freshwater Ecology and Management) Research Group. Departament d'Ecologia, Universitat de \\ Barcelona. Diagonal 645-08028- Barcelona, Spain. \\ *Corresponding author. E-mail: nprat@ub.edu
}

\begin{abstract}
Biological water quality changes in two Mediterranean river basins from a network of 42 sampling sites assessed since 1979 are presented. In order to characterize the biological quality, the index FBILL, designed to characterize these rivers' quality using aquatic macroinvertebrates, is used. When comparing the data from recent years to older ones, only two headwater sites from the 42 had improved their water quality to good or very good conditions. In the middle or low river basin sites or even in headwater localities were river flow is reduced, the important investment to build up sewage water treatment systems and plants (more than 70 in 15 years) allowed for a small recovery from poor or very poor conditions to moderate water quality. Nevertheless still a significant number $(25 \%)$ of the localities remain in poor conditions. The evolution of the quality in several points of both basins shows how the main problems for the recovery of the biological quality is due to the water diverted for small hydraulic plants, the presence of saline pollution in the Llobregat River, and the insufficient water depuration. In the smaller rivers, and specially the Besòs the lack of dilution flows from the treatment plants is the main problem for water quality recovery.
\end{abstract}

Keywords: Long term Biomonitoring, biological water quality, river pollution, Mediterranean rivers.

\section{RESUMEN}

Se presentan los datos de los cambios en la calidad biológica del agua de dos cuencas de ríos mediterráneos, en los que se han estudiado 42 estaciones de muestreo desde el año 1979. Para caracterizar la calidad biológica se usa el índice FBILL diseñado para la caracterización de la calidad de estos ríos usando macroinvertebrados acuáticos. Si se comparan los datos de los años mas recientes con respecto a los mas antiguos, se muestra que solo 2 de las 42 estaciones han aumentado su calidad biológica hasta el grado bueno o muy bueno y son las situadas en las partes altas de la cuenca. En las zonas medias bajas de la cuenca o incluso en partes altas donde el caudal es reducido, la gran inversión realizada en la construcción de depuradoras (mas de 70 en 15 años) se manifiesta en una pequeña mejora de la calidad de las aguas, pues desaparecen muchos de los lugares de calidad deficiente o muy deficiente y muchos sitios se encuentran en situación de calidad moderada pero sin poder llegar a buena. De todas formas todavía un número significativo de puntos (25\%) se encuentra en situación de deficiente calidad. La evolución de la calidad en diversos puntos de las dos cuencas muestra como los principales problemas para la recuperación de la calidad biológica se deben a las derivaciones de agua por minicentrales hidráulicas, a la presencia de una contaminación salina en el río Llobregat y a la insuficiente depuración de las aguas. En los ríos más pequeños, y especialmente en el Besòs, la falta de caudales de dilución de las aportaciones de las depuradoras es el problema principal para la recuperación de la calidad biológica de las aguas.

Palabras clave: Control de calidad biológica del agua, contaminación fluvial, ríos mediterráneos.

\section{INTRODUCTION}

Biomonitoring is the use of biological variables to survey the environment (Gerhartd, 2000). The linkage between management and biomonitoring of freshwater systems reflects the changing needs and demands of human societies in industrialized regions. The early biomonitoring of running waters focused on bacteriological aspects (Kolkwitz \& Marsson, 1902; Hynes, 1960). Starting in the 1970s, "ecosystem health" per se was increasingly seen as a value in many human 
societies (e.g.: Karr, 1999) and the issue is very relevant for ecological theory (Lorenz et al., 1997). At the end of the last century, the necessity of the use of ecological indicators as a main tool in the evaluation of ecosystem health in aquatic ecosystems became evident (Hellawell, 1986, Rosenberg \& Resh, 1992, Resh et al., 1995). Advantages and difficulties of use of different kinds of organisms may be found in many books (Cairns \& Pratt, 1993, Carter \& Resh, 2001). The European Water Framework Directive has made the preservation and restoration of ecological status of freshwater ecosystems a central issue (Irvine, 2004). Many of the issues of using organisms as indicators of ecological status or health have been reviewed recently (Statzner et al., 2001; Adams, 2002; Downes et al., 2002; Simon, 2002; Bonada et al., 2006), and many water agencies use biocriteria as indicators of environmental health (Knoben et al., 1995 in Europe; Bunn, 1995 in Australia; Barbour et al., 1999 in USA).

The interest on long-term studies using the same protocol has been emphasized in many papers, as it has been the usefulness of this kind of studies for evaluating management practices (e.g.: Boyle, 1987). When the monitoring program in the Besòs and Llobregat Rivers was initiated in 1979, one of the objectives was to produce baseline knowledge of the biological conditions of the two streams before the implementation of a massive sewage plant construction plan.

Although biomonitoring has some tradition in Spain going back to the pioneering studies of Margalef (1969), no continuous monitoring programs existed before 1980. The state of the art was reviewed in 1992 by Alba-Tercedor \& Prat (1992). At this time and until very recently (Prat et al., 2001, Jáimez-Cuéllar et al., 2002) no standardized protocols were available and have not been applied by basin management authorities. In Catalonia, and after the work of Margalef (op.cit.) the first papers to be published on biological monitoring were the results from a project encouraged by Margalef himself for a regional environmental authority. As a result, a method to measure biological quality of Mediterranean streams based on macroinvertebrates was developed (Prat et al., 1983 and

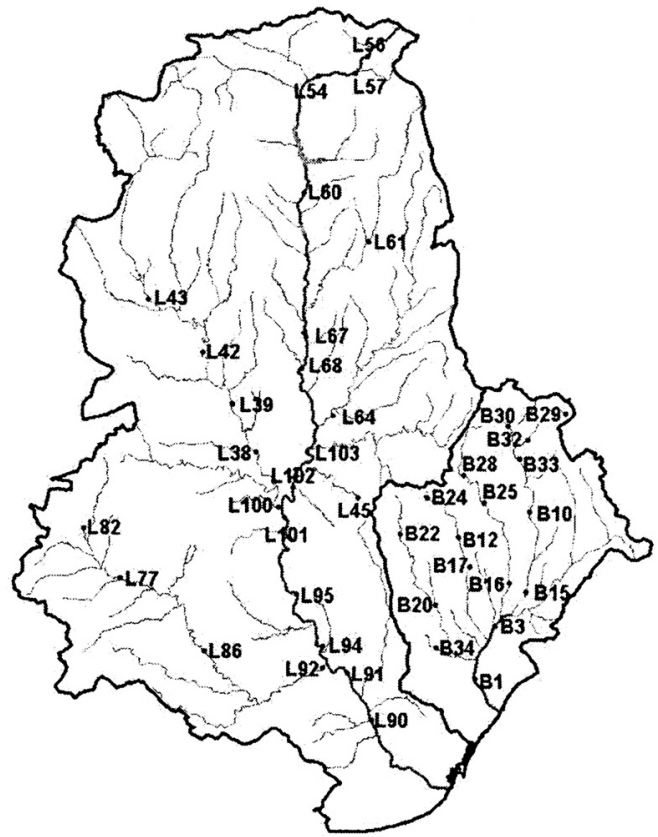

Figure 1. Localization of sampling stations in the studied Besòs (B) and Llobregat (L) river basins. Localización de las estaciones de muestreo en los ríos Besòs (B) y Llobregat (L).

1984). But the initial effort was not followed by the establishment of a regular monitoring program until 1994, when the biomonitoring program ECOBILL was established by Diputació de Barcelona and it has been applied since (Prat et al., 1996; Prat et al., 2005). Therefore, data during the period 1983-1994 are scarce despite an isolated work done in the LLobregat in 198991 (Muñoz \& Prat, 1991).

Using all the data collected in the rivers Besòs and Llobregat since 1979 to the present, we present the evolution of the biological quality of these two streams. Our objective is to describe the change of the biological quality of the two basins during the last 25 years.

\section{STUDY SITES AND METHODS}

The two studied river basins flow into the Mediterranean Sea close to Barcelona city (NE Spain), have medium size watershed area (4984 $\mathrm{km}^{2}$ the Llobregat and $1038 \mathrm{~km}^{2}$ the Besòs), and a Mediterranean flow regime. River Llobregat has its headwaters in the Pre- 
Pyrenean calcareous mountains, and has been extensively described in Prat et al. (1984) and Prat \& Ward (1994). River Besòs has its origins in the siliceous pre-littoral range mountains (Montseny) and its main characteristics can be found in Prat et al. (2000).

The sampling site network of up to 42 stations (25 in Llobregat and 17 in Besòs) was established in 1979 (Fig. 1), covering the main stream zonation, and including permanent and temporary tributaries to natural and strongly regulated sections with nearly constant mean flow.

Macroinvertebrate's samples were always taken using a 250 microns kick net. Sampling protocols were followed, and although quality indexes have slightly evolved along these 25 years, care has been taken to produce comparable results. At the beginning of the study, in 1979-82, the BILL water quality index was designed (Prat et al., 1983), following the Trent Biotic Index

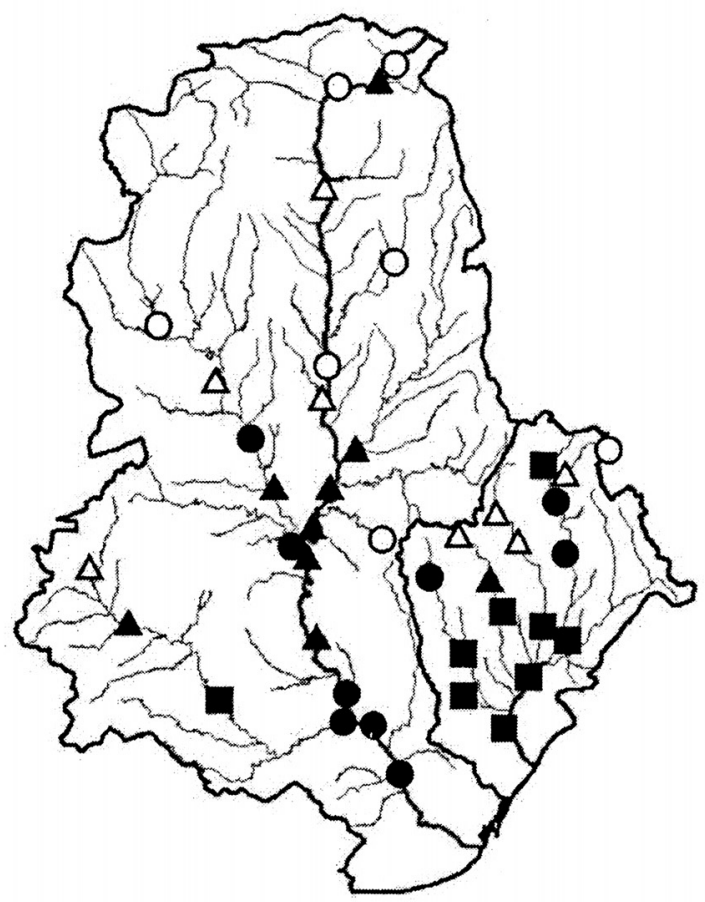

model and adapted to the regional ecological conditions, to be applied on riffle samples. This index was improved and adapted in 1997 to family taxonomical resolution FBILL (Prat et al., 1999) (formerly a mix of taxonomic units, from genera to order level, was needed). A good correlation in water quality class assignment using any of the two indices was found (Prat et al., op.cit.). The FBILL index rationale and calculation may be found in http://www.diba.es/mediambient/ ecostrimed.asp. FBILL index values are ranged in five biological water quality categories: Very good (FBILL 9-10), Good (7-8), Moderate (5-6), Poor (3-4), Very poor (1-2).

Since 1994 the IBMWP index has been applied (Alba-Tercedor \& Sánchez-Ortega, 1988), which requires a multi-habitat sampling procedure, and a more extensive searching of macroinvertebrate's families (GUADALMED protocol, www.guadalmed.org). To allow for

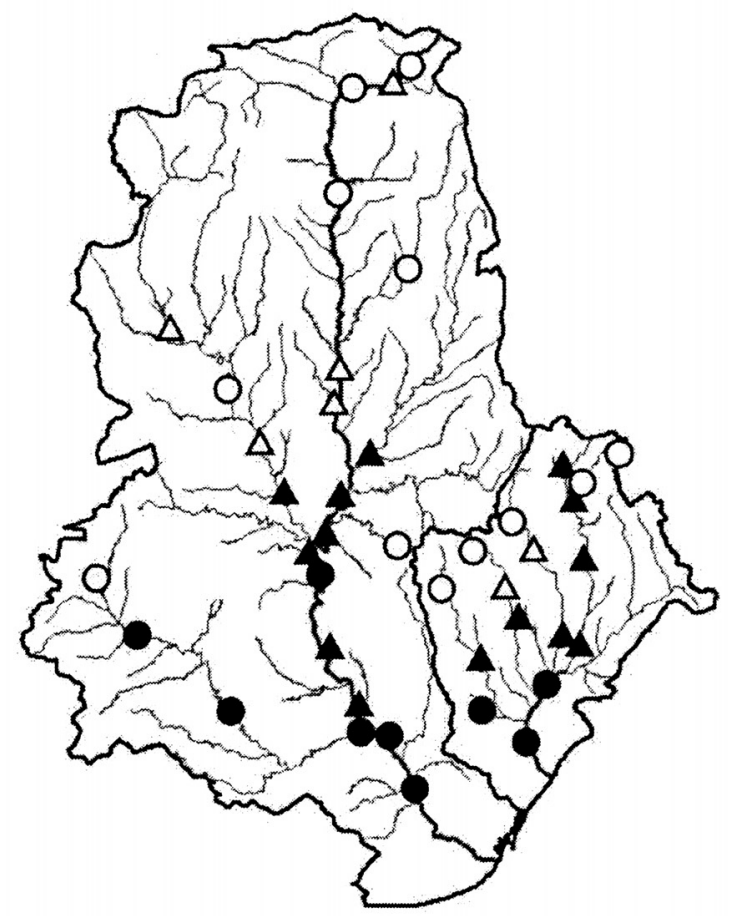

Figure 2. Biological quality of Besòs and Llobregat basins in 1979-80 (upper part) and in 2003-05 (lower part). Symbols indicating each biological water quality ranks measured using FBILL index are as follows: Open circles: 9-10 (very good); Open triangles: 7-8 (good); Filled triangles: 5-6 (moderate); Filled circles: 3-4 (poor); Filled squares: 0-2 (very poor). Calidad biológica de los ríos Besòs y Llobregat en 1979-80 (parte superior) y en los años 2003-05 (parte inferior). Los símbolos indican los intervalos de los valores del índice FBILL y los rangos de calidad biológica de la forma siguiente: Círculos abiertos: 9-10 (muy buen estado); Triángulos abiertos: 7-8 (buen estado); Triángulos negros: 5-6 (estado moderado); Círculos negros: 3-4 (estado deficiente) y Cuadrados negros:0-2 (estado muy deficiente). 

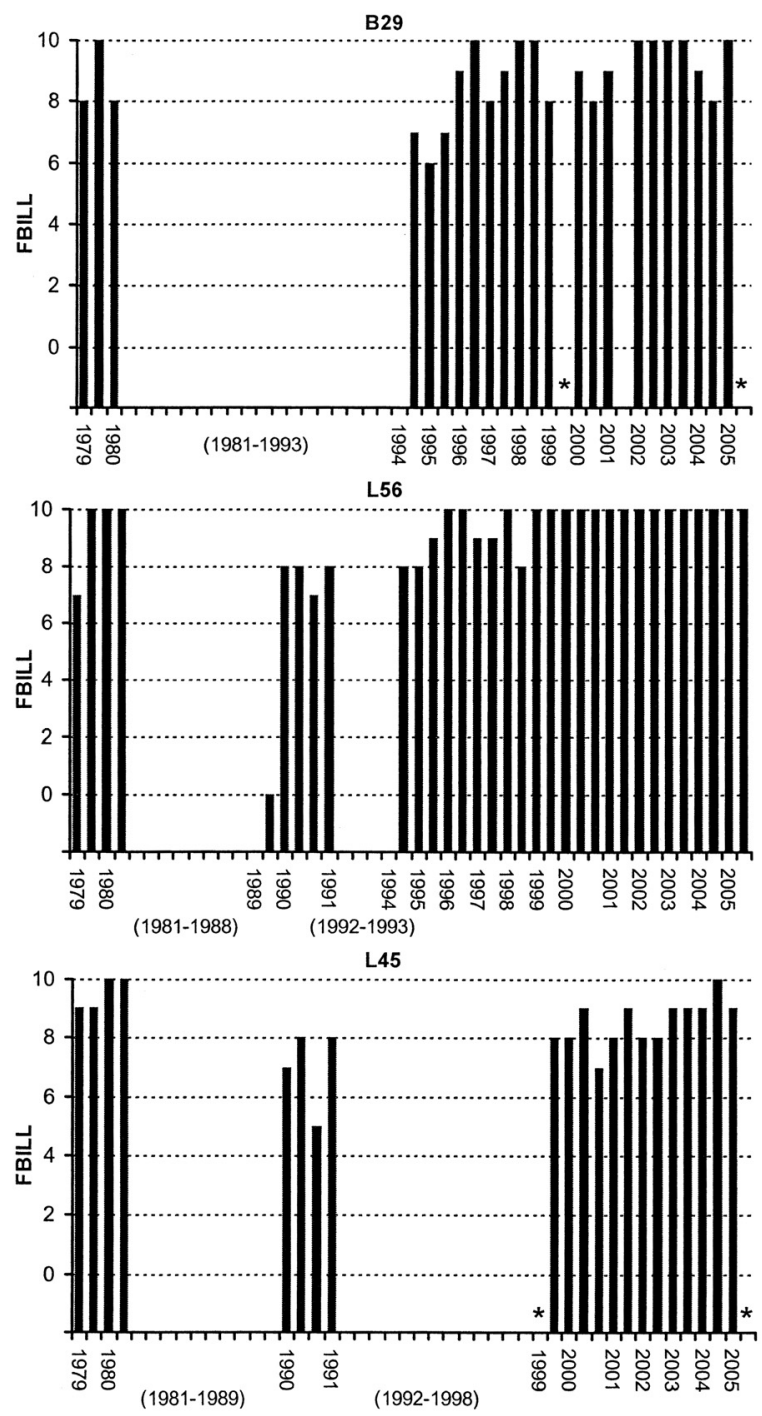

Figure 3. Biological quality of three reference stations, one from Besòs (B29) and two from Llobregat (L45 and L56). * indicates that the river was dry. Calidad biológica de tres estaciones de referencia, una del Besòs (B29) y dos del Llobregat (L45 y L56).

* indica que el río estaba seco.

the comparison with older data, two macrohabitat (riffle and pool) samples were collected and sorted independently, riffle family identification was used afterwards to calculate the FBILL index, and inventories were pooled to calculate IBMWP index.

Each site was visited in two occasions each year (spring and summer). Environmental data included in situ measurements (dissolved oxygen, conductivity, temperature and $\mathrm{pH}$ ) and water samples for nutrients and suspended solids analysis in the laboratory.

\section{RESULTS}

All the data produced during this 25 years of river bioassessment have been published on an annual basis in a collection created for this purpose entitled Estudis de la qualitat ecológica dels rius ('Studies on the Ecological Quality of rivers'), and edited by the Diputació de Barcelona covering the period from 1994 to the present. Earlier studies were also published by the same or other authors (Prat et al., 1983; Muñoz \& Prat, 1991; 1994). Since 2003 (2001 data 
campaign) the edition has changed from paper to CD-Rom, with the advantage of presenting the results and conclusions in an interactive way, and incorporating the entire database cumulatively (e.g.: the last issue Prat et al., 2005).

We present the global situation in figure 2, comparing 1979-80 and 2003-05 biological water quality maps. In the Llobregat River, the only very poor quality site in 1979-80 has since disappeared, but 6 of the 24 monitored sites are still in poor quality status. Only two sites have increased from moderate to good quality during this time. In the Besòs River, changes have been more evident and important; the eight very poor quality sites of the period 1979-80 have improved to poor or moderate quality, while the number of sites of good or very good quality has increased from five to seven.

Water quality changes expressed as FBILL index values in several representative sites of
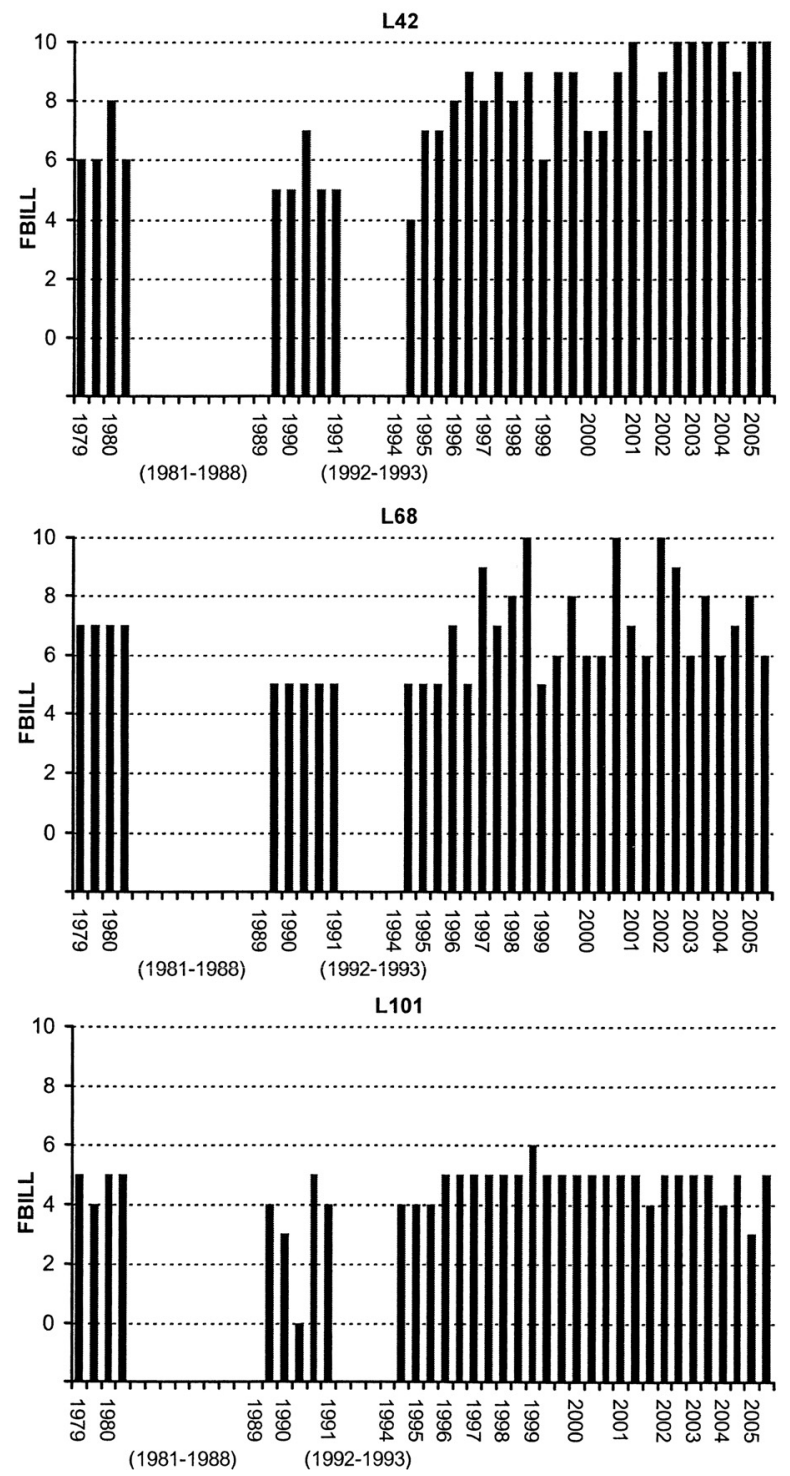

Figure 4. Biological quality of three stations of the middle part of the Llobregat River, before (L42, L68) and after the salt mines (L101). Calidad biológica de tres estaciones de la parte media de la cuenca del río Llobregat, antes (L42, L68) y después de las minas de sal (L101). 
the two basins are shown in figures 3 to 6 . In the three selected reference headwater sites (Fig. 3: B29 in Besòs, L56 in the main Llobregat channel or L45, an undisturbed Llobregat tributary with a small basin area), the FBILL index value has not changed since 1980 and has maintained a good or very good biological quality along all the studied period.

Some sites have improved their ecological status from moderate to good or very good (e.g.: L42, Fig. 4) after the implementation of sewage plants in towns and cities. Mainly sites situated in high or middle parts of the river basins have showed this recovery. In the middle parts of Llobregat River main channel two different situations appear. Above the salt mines (site L68), the biological conditions have recovered from the moderate values of the nineties to good or very good in recent times (Fig. 4). Values variability is related to river flow fluctuations depending on rainfall (wet and dry years). Salt mines down waters (e.g. site L101) do not show significant biological condition changes since the eighties, being at most moderate, despite that similar sewage improvement efforts have been applied.

In the lower Llobregat River (sites L95 and L90, Fig. 4), the biological condition of the river is very much the same after twenty five years, with values of moderate condition at most depending on the year.

In most sites of the Besòs River, water quality has improved clearly from a very poor or poor condition in the eighties to a present moderate status (Figs. 1 and 6) both in the headwaters (B33) and in the middle parts (B16). The improvement was linked to the building up of many
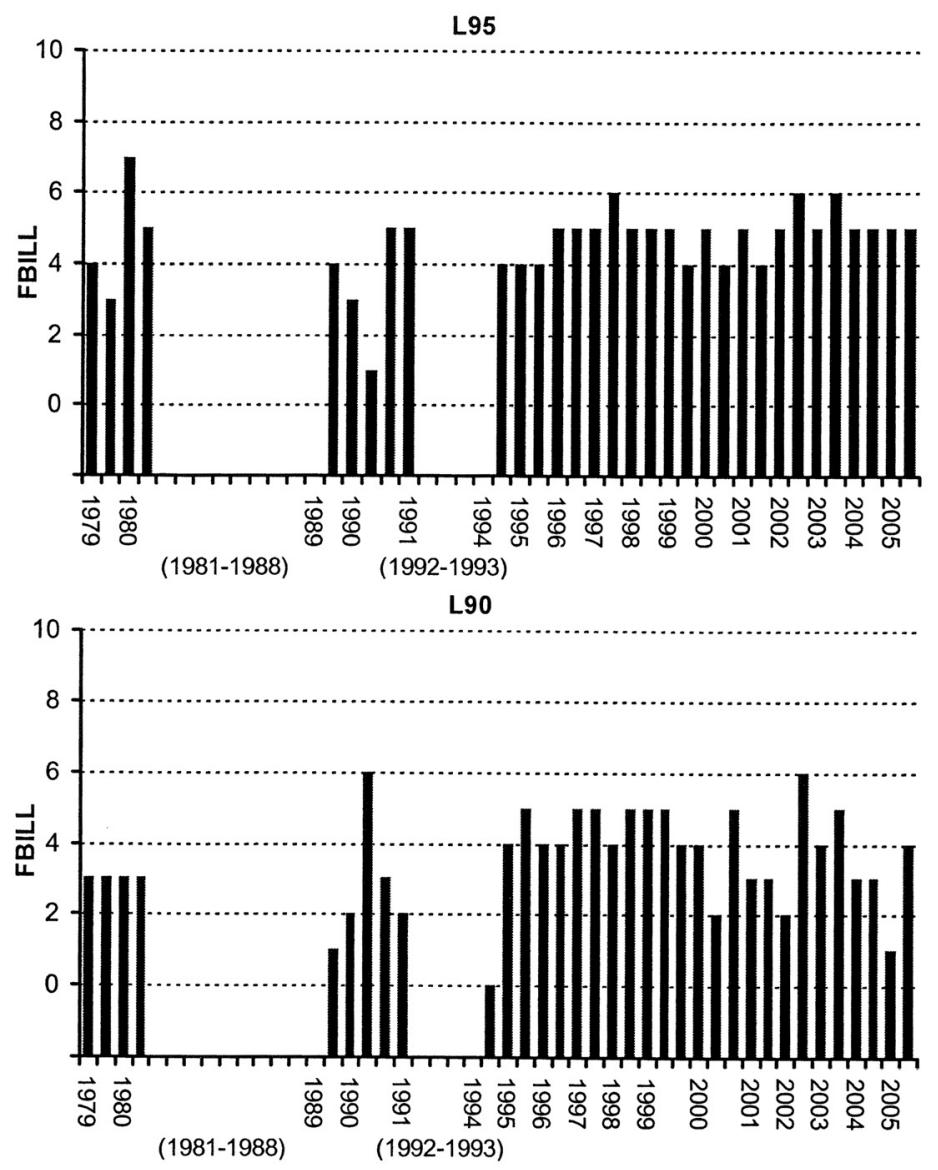

Figure 5. Evolution of biological water quality of two stations of the lower part of the Llobregat River, before (L95) and after (L90) of the entrance of the Anoia River. Evolución de la calidad biológica de dos estaciones de la parte baja del río Llobregat, antes (L95) y después (L90) de la entrada del río Anoia. 
sewage plants in the beginning of the nineties. In the lower parts, though, such effect is not that visible (B1 in Fig. 6) maintaining its status of poor or very poor conditions.

\section{DISCUSSION}

Long-term river bioassessment networks allow for evaluating and sizing the water quality changes after the implementation of water improvement strategies in a wider perspective and including inter-annual variability. By using biotic indices we can summarize the evolution of rivers' biological water quality in a simple way. After 25 years of using the FBILL index in the Llobregat and Besòs river basins, we may evaluate the improvements produced as a result of the investments in urban and industrial sewage water treatments. Very large (more than 1.5 millions population equivalents (p.e.)) to very small (less than 1000 p.e.) sewage plants have been built in the two river basins since the beginning of the nineties and now all except one village up to 2000 people have their own sewage plant.

Despite the great investment effort done (1200 M€ in 15 years approximately), by the Catalan Water Agency (formerly Junta de Sanejament), the biological river water quality is still poor in $25 \%$ of the sites of the Llobregat River and $18 \%$ of the Besòs River. Although there is a general improvement and a net increase in the number of sites in good or very good condition (mostly in the headwaters), they account for less than $50 \%$ of the sites in both basins, which conform to the demands of the Water Framework Directive. From all the sites studied, only two have improved to high or very high status. Both sites are in the higher part of streams with small population densities and where sewage plants have been built. The effectiveness of the sewage plants in these conditions seem to be very high and therefore, sites from the upper river areas of both basins are in good condition. In the Llobregat, the main disturbance in the upper part of the basin is the diversion of water flow with weirs to produce electricity (Prat \&
Ward, 1994). The effects on biological quality of water diversion for hydroelectrical uses is mainly reflected in fluctuations of the index value from moderate condition during the dry years or in summer to very good condition in wet years (L68, Fig. 3). However, when the diversion is very high, the biological quality may became critical (Muñoz \& Prat, 1998).

In the Llobregat River, a key issue for the biological river quality restoration is the salt mining activity that introduces some salt in the river (conductivity is always over 1000 $\mu \mathrm{S} . \mathrm{cm}^{-1}$ ). After the mines the biological quality of the river never increases over FBILL values of 6 and may be even lower in areas below the weirs diverting water for electricity purposes (e.g. L102, Figs. 2 and 3). In the lower part of the Llobregat, apart from the salinity, the river receives many inputs of different sewage plants as well as the inputs from rain polluted water due to urbanization (no separation of rainwater and sewage water is possible in the sewage pipes of many cities of the river basin). For these reason the river water quality has not increased significantly despite the great money investment in sewage in the area (Llobregat River has six poor quality spots in the lower part of the basin).

In the Besòs River the number of sewage plants built by authorities in the last 15 years has been very large, covering almost all the basin. But this Mediterranean stream has a population larger than 2 million people with an intensive use of freshwater from the basin and importing more than $50 \%$ of the water from other basins. The great efforts in sewage (with a central administrative authority, the "Consorci de la Conca del Besòs") have had as a consequence that the very poor biological condition of many parts of the river in the early eighties has disappeared, but still many sites are in poor or moderate condition. In many of the streams of this basin no or weak dilution of the water coming from sewage plants exist, and this is the main reason for the non-recovery of the biological condition of the streams (Prat \& Munné, 2000). Values of ammonia in some of the streams of the lower part are close to $2-4 \mathrm{mg} \mathrm{l}^{-1}$ and 

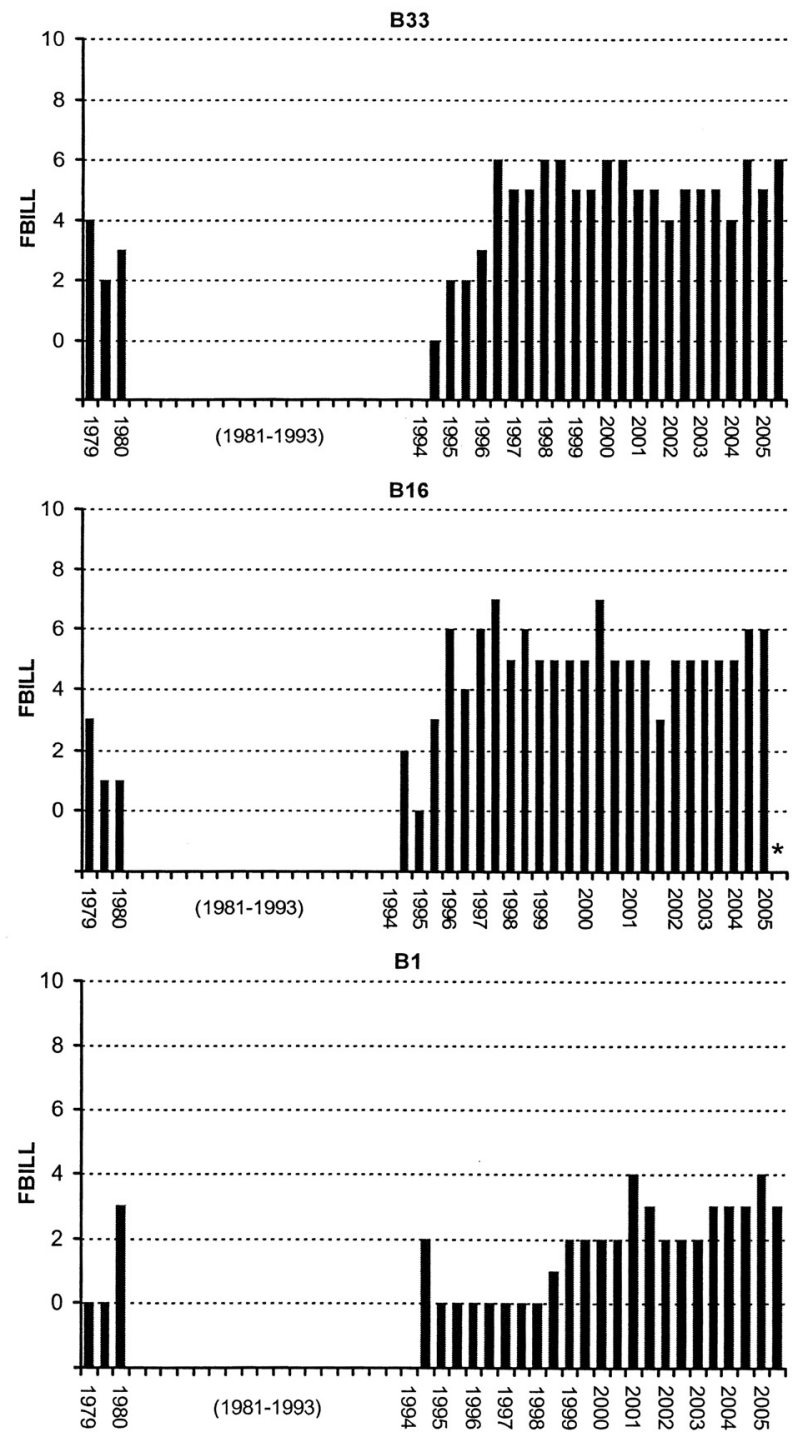

Figure 6. Changes in the biological water quality of three stations of the river Besòs, one in the upper part (B33), the other in the middle area of the basin (B16) and the last one in the lower part (B1). * indicates that the river was dry. Cambios en la calidad biológica del agua de tres estaciones del río Besòs, una en la parte alta (B33) otra en la zona media (B16) y la última en la parte baja (B1). * indica que el río estaba seco.

this fact by itself makes the recovery of biological conditions of these streams impossible.

In conclusion, the enormous effort made by the Catalan Water Authorities building up more than 70 sewage plants in both basins and investing millions of euros has had fruitful consequences in the higher parts of the rivers Llobregat and Besòs were the water coming from sewage plants can be diluted by the natural river flow, but has had little or moderate effect in many other areas. In the future, if the biological condition of river water is to be increased to fulfil WFD requirements, the main issue to solve in the Llobregat River will be salt mine pollution and the water flow derivation for electricity generation. In the Besòs river basin and part of the Llobregat basin the main problem is the lack of dilution and therefore the need for a better treatment of sewage water and an improvement in water efficiency use. 


\section{AKNOWLEDGEMENTS}

During the present period of sampling (since 1994) water has been analysed by Agbar laboratories (Llobregat) and Consorci de la Defensa del Besòs (Besòs river). We would like to acknowledge all members, present or past, of F.E.M. research group and participants of ECOBILL project for their field, lab, and report writing collaboration, and for their never exhausting involvement in freshwater ecosystems conservancy.

\section{REFERENCES}

ADAMS, S. M. 2002. Biological indicators of aquatic ecosystem stress: introduction and overview. In: Biological indicators of aquatic ecosystem stress. (S.M. Adams, ed.): 1-11. American Fisheries Society, Maryland.

ALBA-TERCEDOR, J. \& N. PRAT. 1992. Spanish experience in the use of macroinvertebrates as biological pollution indicators. River Water Quality Assessment and Control. CCEE, 733-738. Bruselas Bélgica.

ALBA-TERCEDOR, J. \& A. SÁNCHEZ ORTEGA. 1988. Un método rápido y simple para evaluar la calidad biológica de las aguas corrientes basado en el de Helawell (1978). Limnetica, 4: 51-56.

BARBOUR, M. T., J. B. STRIBLING \& J. R. KARR. 1995. Multimetric approach for establishing biocriteria and measuring biological condition. In: Biological assessment and criteria. Tools for water resource planning and decision making. W. S. Davis \& T. P. Simon (eds.): 63-77. Lewis Publishers. Boca Raton, Florida.

BONADA, N., N. PRAT, V. H. RESH \& B. STATZNER. 2006. Developments in Aquatic Insect Biomonitoring: A Comparative Analysis of Recent Approaches. Annual Review of Entomology, 52: 495-523.

BOYLE, T. (ed.). 1987. New approaches to monitoring aquatic ecosystems. ATSM International. 465 pp.

BUNN, S. E. 1995. Biological monitoring of water quality in Australia: Workshop summary and future directions. Australian Journal of Ecology, 20: 220-227.

CAIRNS, J. Jr. \& J. R. PRATT. 1993. A history of biological monitoring using benthic macroinvertebrates. In: Freshwater biomonitoring and benthic macroinvertebrates. D. M. Rosenberg \& V. H. Resh, (Eds.): 10-27. Chapman and Hall, New York.
CARTER, J. L. \& V. H. RESH. 2001. After site selection and before data analysis: sampling, sorting, and laboratory procedures used in stream benthic macroinvertebrate monitoring programs by USA state agencies. Journal of the North American Benthological Society, 20(4): 658-682.

DOWNES, B. J., L. A. BARMUTA, P. G. FIARWEATHER, D. P. FAITH, M. J. KEOUGH, P. S. LAKE, B. D. MAPSTONE, \& G. P. QUINN. 2002. Monitoring ecological impacts. Concepts and practice in flowing water. Cambridge Univ. Press, $434 \mathrm{pp}$.

GERHARDT, A. 2000. Biomonitoring of polluted water. Trans Tech Publications Ltd, Switzerland. $120 \mathrm{pp}$.

HELAWELL, J. 1986. Biological indicators of freshwater pollution and environment management. Elsevier. 546 pp.

HYNES, H. B. N. 1960. The Biology of Polluted Waters. Liverpool University Press, Liverpool. $495 \mathrm{pp}$.

IRVINE, K. 2004. Classifying ecological status under the European Water Framework Directive: the need for monitoring to account for natural variability. Aquatic Conservation: Marine and Freshwater Ecosystems, 14: 107-112.

JÁIMEZ-CUÉLLAR, P., S. VIVAS, N. BONADA, S. ROBLES, A. MELLADO, M. ÁlVAREZ, J. AVILÉS, J. CASAS, M. ORTEGA, I. PARDO, N. PRAT, M. RIERADEVALL, C. SÁINZ-CANTERO, A. SÁNCHEZ-ORTEGA, M. L. SUÁREZ, M. TORO, M. R. VIDAL-ABARCA, C. ZAMORAMUÑOZ \& J. ALBA-TERCEDOR. 2002.Protocolo GUADALMED (PRECE). Limnetica. 21: 187-204.

KARR, J. R. 1999. Defining and measuring river health. Freshwat. Biol., 41, 221-234.

KNOBEN, R. A. E., C. ROOS \& M. C. M. VAN OIRSCHOT. 1995. Biological assessment methods for watercourses. UN/ECE Task Force on Monitoring \& Assessment 3. 86 pp.

KOLKWITZ, R. \& M. MARSSON. 1902. Grundsätze für die biologische Beurtheilung des Wassers nach seiner Flora und Fauna. Mitteilungen aus der Königlichen Prüfungsanstalt für Wasser und Abwasser, 1, 3-72.

LORENZ, C. M., G. M. VAN DIJK, A. G. M. VAN HATTUM \& W. P. COFINO. 1997. Concepts in river ecology: implications for indicator development. Regulated Rivers: Research \& Management, 13: 501-516.

MARGALEF, R. 1969. El concepto de polución en limnología y sus indicadores biológicos. Agua, Suplemento 7: 105-133. 
MUÑOZ, I. \& N. PRAT. 1991. Cambios en la calidad del agua de los ríos Llobregat y Cardener en los últimos 10 años. Tecnología del Agua, 91: 17-23.

MUÑOZ, I. \& N. PRAT. 1998. Effects of water abstraction and pollution on macroinvertebrate community in a mediterranean river. Limnetica, 12(1): 9-16.

MUÑOZ, I. \& N. PRAT. 1994. A comparison between different biological water quality indexes in the Llobregat Basin (NE Spain). Verh. Intern. Verein. Limnol., 1(25): 1945-1949

PRAT, N. \& J. V. WARD. 1994. The Tamed River. In: Lymnology Now. R. Margalef (ed.): 219-236. London: Elsevier Science.

PRAT, N. \& A. MUNNÉ. 2000. Water use and quality and stream flow in a mediterranean stream. Water Research, 34(15): 3876-3881.

PRAT, N., M. A. PUIG \& G. GONZÁLEZ. 1983. Predicció $i$ control de la qualitat de les aigües dels rius Besós i Lobregat. II. El poblament faunístic i la seva relació qualitat-aigües. Barcelona: Diputació de Barcelona. Col. Monografies. Volum 9. $164 \mathrm{pp}$.

PRAT, N., M. A. PUIG, G. GONZÁLEZ, M. J. TORT \& M. ESTRADA. 1984. The Llobregat: A Mediterranean river fed by the Pyrenees. In: Ecology of European Rivers. (B. A. Whitton, ed.): 527-552. Blackwell Scientific Publications, Oxford, UK.

PRAT, N., M. RIERADEVALL, A. MUNNÉ \& G. CHACÓN. 1996. La qualitat ecològica de les aigües del Besòs i el Llobregat. Diputació de Barcelona. Servei de Medi Ambient. Col. Estudis de la qualitat ecològica dels rius. Volum 1.102 pp.

PRAT, N., M. RIERADEVALL, A. MUNNÉ, C. SOLÀ \& G. CHACÓN. 1998. La qualitat ecològica del Besòs $i$ el Llobregat- Informe 1996. Els cabals del riu Congost. Barcelona: Diputació de Barcelona. Servei de Medi Ambient. Col. Estudis de qualitat ecològica dels rius. Volum 2. $153 \mathrm{pp}$.

PRAT, N., A. MUNNÉ, C. SOLÀ, M. RIERADEVALL \& N. BONADA. 1999. La qualitat ecològica del Llobregat, el Besòs i el Foix. Informe 1997. Barcelona: Diputació de Barcelona. Servei de Medi Ambient. Col. Estudis de qualitat ecològica dels rius. Volum 6. 154 pp.

PRAT, N., A. MUNNÉ, M. RIERADEVALL, F. CARCELLER, J. FONS, G. CHACÓN, J. J. IBÁÑEZ, X. FONT, J. M. CARMONA \& A. ROMO. 2000. Biodiversity of a Mediterranean stream drainage network. Verh. Intern. Verein. Limnol., 27: 135-139.

PRAT, N., A. MUNNÉ, M. RIERADEVALL, C. SOLÀ, \& N. BONADA. 2001. ECOSTRIMED. Protocol per determinar l'estat ecològic dels rius mediterranis. Barcelona: Diputació de Barcelona, Àrea de Medi Ambient. Col. Estudis de la qualitat ecològica dels rius. Vol. 8. 94 pp.

PRAT, N., M. VILA-ESCALÉ, N. BONADA, R. CASANOVAS-BERENGUER，T. PUNTÍ, C. SOLÀ, J. JUBANY, M MIRALLES, M. ORDEIX, R. ACOSTA, B. RÍOS, R. ANDREU \& M. RIERADEVALL. 2005. La qualitat ecològica del Llobregat, el Besòs $i$ el Foix. Informe 2003. Barcelona: Diputació de Barcelona. Servei de Medi Ambient. Col. Estudis de qualitat ecològica dels rius. Volum 13. Edición CD-Rom.

RESH, V. H., R. NORRIS \& M. T. BARBOUR. 1995. Design and implementation of rapid assessment approaches for water resource monitoring using benthic macroinvertebrates. Australian Journal of Ecology, 20: 108-121.

ROSENBERG, D. M. \& V. H. RESH (eds.). 1992. Freshwater biomonitoring and benthic macroinvertebrates. Chapman \& Hall. 488 pp.

SIMON, T. P. (ed.). 2002. Biological Response Signatures. CRC press. 450 pp.

STATZNER, B. \& F. SPERLING. 1993. Potential contribution of system-specific knowledge (SSK) to stream management decisions: ecological and economic aspects. Freshwat. Biol., 29: 313-342.

STATZNER, B., B. BIS, S. DOLÉDEC \& P. USSEGLIO-POLATERA. 2001. Perspectives for biomonitoring at large spatial scales: a unified measure for the functional composition of invertebrate communities in European running waters. Basic and Applied Ecology, 2: 73-85. 